\title{
IMPLEMENTATION OF THE ISLAMIC CRIMINAL LAW IN MALAYSIA: PROSPECTS AND CHALLENGES $* *$
}

\author{
Tun Abdul Hamid Mohamad*
}

First of all, I would like to correct a common mistake. Many people thought that Brunei has implemented hudud law. That is not correct. In fact, to this day, Brunei has yet to enforce that part of the Syari'ah Penal Code Order 2013 which contains hudud offences. Brunei has gazetted the law. The effective date has not been fixed yet. The most recent information I received from the Assistant Solicitor General of Brunei on $15^{\text {th }}$ December, 2014 confirmed that the hudud law has not been enforced. In fact, the provisions of the Syari'ah Criminal Procedure Code necessary for the implementation are still under discussion.

If we want to talk about criminal law and what is now called "Islamic criminal law", in the Malaysian context, we have to start from the Federal Constitution.

Criminal law is placed under federal jurisdiction. The Constitution does not define "criminal law". However, the offences that had existed in the Penal Code at the time the Constitution was enacted, must necessarily be "criminal law". If not, what else? The words "Islamic criminal law" are not used at all. What is provided is:

“.... Creation and punishment of offences by persons professing the religion of Islam against precepts of that religion, except in regard to matters included in the Federal List;"

Note the conditions mentioned:

1. offences committed by persons professing the religion of Islam,

2. against precepts of that religion

3. except in regard to matters included in the Federal List;

Do not misunderstand and think that "criminal law" is under federal jurisdiction, while the "Islamic criminal law" is under the jurisdiction of the state. The Constitution only allows the State Legislature to enact laws for offences committed by persons professing the religion of Islam against the precepts of Islam, even then if it is not in respect of matters included in the Federal List, that is, "criminal law". Apart from that, there are also restrictions, such as the provisions of the Syari'ah Court (Criminal Jurisdiction) Act 1965 (Act 355).

To understand why the division of powers regarding criminal law and "offenses against the precepts of Islam" was made in such a way, we have to understand the situation in the Malay Peninsula at that time. 
Throughout the history of the Malay States, the Sultan was the Head of Islam in his State and matters concerning Islam were always under the authority of the Sultan and the State. Before Merdeka there was no "religion of the Federation". In fact, the Malay Rulers objected to UMNO's proposal to make Islam the official religion of the Federation. Maybe, the Rulers feared that their power as Head of Religion in their respective states would be undermined. Since the establishment of the Malayan Union and the Federation of Malaya, criminal law came under the Federal jurisdiction.

Not only that, one of the Terms of References given to the Reid Commission was to create a strong federation. That is why, amongst others, external affairs, defence and internal security are placed under federal jurisdiction. Regarding law, Civil and criminal law and procedure and the administration of justice are placed under federal jurisdiction. Those laws (particularly criminal law) are general laws that involve public order and national security and the application of which is not limited to Muslims only or to the border of a state only.

The implementation is supported by the Police Department, the Department of Prisons and the Civil Court whose jurisdiction covers the whole country. It should be remembered that, international agreements on cooperation in combating crimes such as Interpol are agreements between country and country. International law does not recognise a state like Kelantan. It recognises countries like Malaysia to become parties in the agreements. Extradition law also involves countries, not states.

The State Legislature is given power to make law for the "creation and punishment of offences by persons professing the religion of Islam against precepts of that religion, except in regard to matters included in the Federal List;" That is all.

As far as I know, at that time, neither states nor groups had sent a memorandum to the Reid Commission proposing that criminal law be placed under State Governments. Although PAS was already in existence, PAS too did not think it that way at that time. In fact, In Kelantan, at that time, there was a group that wanted Kelantan to secede from Malaya.

At the same time too, religious matters which fell under the jurisdiction of the states were limited to family law. In most states, there were no Syari'ah courts then.

It was under those circumstances that provisions regarding criminal law and offences against precepts of Islam were enacted. Thus, criminal law is placed under federal jurisdiction.

Since $7^{\text {th }}$ January, 2014, I have spoken five times on the implementation of hudud in Malaysia. Let me reiterate the points that I have made. 
First, criminal law is under federal jurisdiction and offences by persons professing the religion of Islam against the precepts of Islam, except in regard to matters included in the Federal List, is under the jurisdiction of the state. Both the Federal Parliament and the State Legislative Assembly may not make law with regard to matters under the jurisdiction of the other.

Second, offences that have existed in the Penal Code since 1936 and in force when the Federal Constitution was enacted, for example, causing of death to others, theft, robbery, rape and causing injury to other persons, necessarily fall within the words "criminal law" used by the drafters of the Constitution. If not, what else is "criminal law"? Further, if not, then all the trials of offences under the Penal Code in Civil Courts since Merdeka are unconstitutional, null and void. That is an unreasonable proposition.

Third, among the hudud offences, there are "criminal law" offences provided for in the Penal Code while others are not. There are offences that have already been provided for in the Shari'ah Criminal Offences Enactments of the states. For example, adultery, accusing another person of committing adultery and offences associated with consumption of alcoholic drinks. It is arguable that such offences are not "criminal law".

Fourth, if hudud punishments were to be imposed for federal offenses, it can only be done as a federal law, that is, as "criminal law", not as "offences relating to precepts of Islam" as provided in List II (State List), the Ninth Schedule of the Constitution. There is no constitutional barrier for doing so. Parliament may choose whatever punishment for any criminal offence, including punishments in accordance with Shari'ah. The law would apply to Muslims and non-Muslims. As criminal law it is under the jurisdiction of the Civil Court. Civil Court has jurisdiction over Muslims and non-Muslims. For the Malaysian Parliament to make such a law, no amendment of the Constitution is necessary and the bill need only be passed by a simple majority. This situation may be compared to the law on Islamic banking and finance and takaful.

Fifth, it should be emphasised that the federal criminal law must apply to all Muslims and non-Muslims because it is a general and not a private law and offenses provided for in the State List. If it is made applicable only to Muslims, it contravenes the provisions of Article 8 of the Constitution because it is discriminatory on ground only of religion and therefore unconstitutional, null and void.

Sixth, with regard to offenses that are not provided for in the Penal Code or any other federal law, but have already been provided for in the Syari'ah Criminal Law Enactment States, they may be made hudud offenses under state law if the existing obstacle is removed. The obstacle is not a constitutional obstacle but an 
obstacle by federal law that limits the punishments that could be provided in the state law and given jurisdiction to the Syari'ah Court. That law is the Syari'ah Court (Criminal Jurisdiction) Act, 1965. If the Federal Government is willing to amend the act to allow the State Legislature to impose hudud punishment, the State Legislative Assembly may make such a law. As the law is a state law under List II of the Ninth Schedule (State List) it applies only to Muslims and falls under the jurisdiction of the Syari'ah Court. There is no constitutional issue here.

If we do that, the effect will be that some hudud offences would be a federal criminal law that applies to all Muslims and non-Muslims and tried by the Civil Court. Besides, there will also be hudud offences which are under the state law that only apply to Muslims and are administered by Syari'ah Court. Should we have such laws? I leave it to you to answer for yourself.

Seventh, most people think that, because the offences are hudud offences and because Islam is under the jurisdiction of the state, the State Legislative Assembly may make such laws. At most, that view is only partly right. In Malaysia, any law made must be in compliance with the Federal Constitution. As I have mentioned earlier, some of the offenses are under the jurisdiction of the Federal Government and Civil Courts. If the offences are made offenses under state law it is unconstitutional, null and void.

If the State Legislative persists in doing so, its application will not cover nonMuslims. The reason is, the Constitution only empowers the State Legislative to make laws that apply to people who profess the religion of Islam. So if the State Legislature makes it applicable also to non-Muslims, the law is unconstitutional, null and void. Syari'ah Court has no jurisdiction over non-Muslims. If the State Legislative Assembly makes a law to empower the Syari'ah Court to try nonMuslims, the law is also unconstitutional, null and void.

Eighth, we often hear people saying that such offences will only be made applicable to Muslims. It is only partly right. The reasons are:

1. with regard to federal criminal offenses, such offenses are not personal law or "offences relating to the precepts of Islam" as provided in the State List. It is a public law. That is why prosecution is done by the Public Prosecutor, on behalf of the country.

2. As I have said earlier, if the law imposing hudud punishments for criminal offences under federal jurisdiction applies to Muslims only, it is inconsistent with Article 8 of the Federal Constitution and, therefore unconstitutional, null and void. 


\section{Syari'ah Criminal Code (II) Enactment 1993 (Kelantan)}

In my papers since $7^{\text {th }}$ January 2014 I said that the Syari'ah Criminal Code (II), 1993 (Kelantan) is null and void because it is unconstitutional because it creates hudud offenses, including offenses which are under the federal jurisdiction, besides legislating on other federal criminal law offences.

For offences which are within the jurisdiction of the State, it is also null and void because it conflicts with federal law, that is, the Syari'ah Courts (Criminal Jurisdiction) Act 1965, mentioned earlier.

On $2^{\text {nd }}$ April 2014, the Kelantan Exco had decided to move a Private Bill in Parliament to seek Parliament's for the State Legislature to make laws on matters that are within federal jurisdiction, as provided for by Article 76A(1) of Federal Constitution. In his press statement, the Menteri Baser, among others, reportedly said:

"He said, most of the hudud and qisas offences such as theft, robbery, rape, causing injury and murder are within the jurisdiction of the federal government as provided in the Penal Code ......"

From the statement, it appears that the State Government accepted my view that a part of the Kelantan Hudud Enactment was invalid because it violated the provisions of the Federal Constitution. Therefore, to solve it, they decided to seek Parliament's approval for the State Legislative Assembly to legislate on such (federal) offences and impose hudud punishment for them. They rely on Article $76 \mathrm{~A}(1)$ of the Federal Constitution.

In the papers I had also tried to guess how Kelantan would find a way to solve the problems and the issues that may arise afterwards. This is what I said, assuming that Parliament permits and the State Legislative Assembly makes the law and provides hudud punishment for the offences, what is the legal position of the law? Does it remain as "criminal law" or does it become a law made under the State List? In my view, its nature remains as "criminal law". I say this because:

1. From the beginning the offences are criminal law offences within federal jurisdiction. They are not included in the State List. That is why the state had to request permission under Article 76A(1).

2. Parliament does not amend the Constitution to place the offences under the State List. What Parliament does is only to permit the State Legislative Assembly to make law on the subject to be enforced in the state. The nature of the law does not change. I emphasise that in order to place it under the State List, it would require amendments to the Constitution and a majority of two thirds. 
If that is the case, what is the effect of such law? In my opinion:

1. It must be applicable to all, Muslims and non-Muslims because it is a federal criminal law and not a law made under the State List. Otherwise it is unconstitutional as it contravenes Article 8 .

2. Which court has the jurisdiction to try such cases? The answer is, Civil Courts. The reason is, first, it is criminal law and not a law made under the State List. Second, the Civil Court has jurisdiction over Muslims and nonMuslims while Syari'ah Court only has jurisdiction over the Muslims.

\section{The Syari'ah Criminal Code (II) (1993) 2015 Enactment}

On March 18, the bill was tabled in the Kelantan State Legislative Assembly and was subsequently passed. Looking at its contents, all the problems that I had mentioned in regard to the Syari'ah Criminal Code (II), 1993 (Kelantan) Enactment still exist. Apparently, the State Government's strategy is to make the law first. Then it will try to get the approval of the Parliament under Article 76A (1).

The question is, without the prior approval of Parliament, can the State Legislative Assembly make the law? In my opinion, no because at the date the State Legislative Assembly passed the bill, it had no jurisdiction to do so. Only when Parliament gives the permission that the State Legislative Assembly is vested with the jurisdiction to make the law.

To me, the law is null and void for reasons similar to those that I gave for the Syari'ah Criminal Code (II), 1993 (Kelantan) Enactment. Briefly, the reasons are:

1. State Legislative Assembly makes the law as a law that is under the State List, while some of the offenses are "criminal law" under federal jurisdiction. To this day the Ninth Schedule is not amended to place the offences under the State List.

2. Parliament does not or has not given the permission to the State Legislative Assembly to make law with respect to such offenses. Even if subsequently, permission is given, it will not make the law a valid law, because when it was made, it was made without jurisdiction.

3. Even if Parliament gives the permission, the offences remain as criminal law under the jurisdiction of the civil courts and not offenses under the State List because the Ninth Schedule has not been amended to transfer such offenses from the Federal List to the State List. By reason of such offences remaining as criminal law, the law cannot be made applicable to Muslims only. It violates the provisions of Article 8 of the Federal Constitution. 
4. With regard to offences which are under the State List (such as adultery and drinking of intoxicating drink), the law violates the provisions of the Syari'ah Courts (Criminal Jurisdiction) Act 1965.

(Reasons 1 to 4 are also applicable to qisas and ta'zir offenses in the Bill. In other words, they are also void on the same grounds).

\section{The Way out}

Within the framework of the Constitution that exists now, what can be done are:

First Option

a. the State Legislative Assembly may make law for offences under the State List (e.g. adultery, accusing a person of committing adultery and drinking intoxicating drink) and provide $h u d u d$ punishments for them. But Parliament must first amend the Syari'ah Court (Criminal Jurisdiction) Act 1965 to allow the State Legislative Assembly to do so. The law is the law under the State List, applicable only to Muslims and administered by the Syari'ah Court.

b. Besides implementing the First Option (a), the State Government may request the permission of Parliament under Article 76A(1) with regard to hudud offences under the federal jurisdiction (for example, causing death, theft, robbery) and also for qisas and ta'zir offences. If permission is granted, the State Legislative Assembly may make laws on them and provide hudud, qisas and ta'zir punishments for them. But the law is criminal law, applies to Muslims and Non-Muslims and is administered by the Civil Court.

Second option

a. The first option (a) is implemented too.

b. With regard to hudud offenses which are under federal jurisdiction (e.g. causing death, theft, robbery) and also for qisas and ta'zir offences, Federal Parliament may make law providing hudud, qisas and ta'zir punishments for them. It can be done by amending the Penal Code with a simple majority. The law is criminal law, applies to Muslims and non-Muslims and is administered by the Civil Court. If it is necessary for Syari'ah Judges to hear such cases, then people who are qualified to be Magistrates, Judges of the Sessions Court and Judges of the Superior Court, and also qualified in Syari'ah, if any, may be appointed to the posts.

The options mentioned above do not involve amendment to the Constitution. 
It should be noted that, for the Second Option (b) the power lies with the Federal Government. Whether the Federal Government is willing to do it or not or able to do it or not, is another matter.

Whether the first or the second option is chosen, it is not a satisfactory solution. From the legal and administrative perspective, it will create new problems that did not exist before.

Do not blame the Constitution for it. The Constitution does not envisage such things. It clearly divides the jurisdiction over criminal law and jurisdiction over offences against the precepts of Islam. The problem arises when the State Government tries to take over the legislative power over criminal offences that lie under the Federal jurisdiction. That is the root cause of the problem.

\section{Conclusion}

In this speech I do not comment on the detail provisions of the Enactment. I also do not discuss other options that would involve amendments to the Constitution. That is because each of these would require a separate paper. Insya Allah, if invited and if my health permits, I will do it.

This Enactment, if implemented, would change the whole structure of criminal law in Malaysia. Actually, the state (Kelantan) is trying to take over the jurisdiction over criminal law from the federation, in the name of Islam. As a result, while in other states, criminal law is under federal jurisdiction, applicable to Muslims and non-Muslims and administered by the Civil Courts, in Kelantan part of it will be under the jurisdiction of the state, applicable only to Muslims and administered by the Syari'ah Court, while another part will remain under the federal jurisdiction, applicable to Muslims and non-Muslims and administered by the Civil Courts. Is that what the State and Federal Governments wish? It is a matter of policy for them to answer. In doing so, I hope they realise the full implications.

With respect, on the issue of hudud, I find that there is a lot of confusion regarding the law and the implementation. We should be able to differentiate the discussion regarding the law and discussion regarding the implementation. What we are discussing now is the implementation. We are not questioning the law. To raise issues that should be considered in the implementation is not challenging the law. Caliph Umar Ibn Al-Kattab suspended the implementation of hudud during a famine. No one accused him of challenging hudud and challenging God's law. He only decided that, in that situation, at that time, it was not suitable, indeed it would lead to injustice if the application of hudud were to be continued. So, he suspended its application. Remember, hudud is only a means, not the end. The end is justice. 
Something similar happened in Pakistan in our time. When the Hudood Ordinance was enacted in 1979, the offence of rape was made a hudud offence. Subsequently, there were cases of injustice to victims of rape who became pregnant as a result of it and who could not produce the required number of witnesses ending in being convicted of adultery. In 2006, the offence of rape was removed from the Hudood Ordinance and placed under the Penal Code again and tried by the Civil Court, until now.

I am aware that my speech may disappoint many people. But, if you want to hear my honest opinion about the reality from the perspective of the Constitution and the law, that is it. Borrowing the words of Imam Abu Hanifah, "This is only my opinion. If there is a better argument follow it." I would add, "If there is a better argument, I too will follow it."

I believe the question whether the Enactment is constitutional or not will eventually go to court. The court having jurisdiction to decide the issue is the Civil Court because it is a constitutional issue. I would like to see what the Federal Court says about it.

Thank you.

tunabdulhamid@gmail.com

http://www.tunabdulhamid.my

\section{Notes}

* Tun Abdul Hamid Bin Haji Mohamad read law at the University of Singapore (LL.B (Hons)) in 1969. He was appointed as the Chief Justice of Malaysia in 2007 and retired in 2008. He is still active as Chairman of the Law Harmonising Committee of Bank Negara Malaysia, and a member of the Shari'ah Advisory Council of Bank Negara and the Securities Commission, he is also a member of the Judicial Appointments Commission. He can be contacted at tunabdulhamid@ gmail.com and http://www.tunabdulhamid.my.

** This paper was presented as keynote address at Seminar on Implementation of Hudud in Malaysia - History and the Future organised by Department of Syari'ah Faculty of Islamic Studies, UKM and Tuanku Mizan Zainal Abidin Mosque, Putrajaya on $1^{\text {st }}$ April 2015. 